\title{
Recent Advances in X-Ray Structures of Metal-Phenoxyl Radical Complexes
}

\author{
Yuichi Shimazaki \\ College of Science, Ibaraki University, Mito, Japan \\ Email: yshima@mx.ibaraki.ac.jp
}

Received January 19, 2013; revised March 6, 2013; accepted April 15, 2013

Copyright (C) 2013 Yuichi Shimzaki. This is an open access article distributed under the Creative Commons Attribution License, which permits unrestricted use, distribution, and reproduction in any medium, provided the original work is properly cited.

\begin{abstract}
An "experimental" valence state of metal complexes is sometime different from the "formal" oxidation state, especially in the species having redox active ligands. This difference can be seen in biological system, such as iron(IV)-porphyrin $\pi$-cation radical in some heme proteins and copper(II)-phenoxyl radical in galactose oxidase (GO). Although structural characterizations of these species by X-ray diffraction methods have been rare due to their stability, some artificial metal-phenoxyl radical complexes have been synthesized and successfully characterized by X-ray crystal structure. In this review, syntheses and X-ray crystal structures of the one-electron oxidized metal-phenolate complexes, metalphenoxyl radical, and high-valent metal phenolate species are discussed.
\end{abstract}

Keywords: Phenoxyl Radical; Metal Complexes; Oxidation; Valence State; Crystal Structure; Electronic Structure; Reactivity

\section{Introduction}

The oxidation chemistry of metal complexes has been widely developed in recent years, affording deep insights into the reaction mechanisms for many useful homogeneous catalytic reactions and reactions at the active site of metalloenzymes [1].

Some oxidative reaction intermediates have been successfully characterized by various methods [2-11], and especially X-ray crystal structure analysis of some intermediates revealed the geometrical change in the reaction and the oxidant binding structure of metal complexes [5-12]. On the other hand, the oxidation state of the metal ions in the active species has not been fully understood, because the oxidation locus on oxidized metal complexes is often different from the "formal" oxidation site [13-15]. The "formal" and "experimental" oxidation numbers are frequently used as synonyms, since the term of the physical or experimental oxidation state has not been accepted in some areas of chemistry.

The valence state difference began to attract attention in early 1990's from the studies on galactose oxidase (GO) [16-18]. GO is a single copper oxidase, which catalyzes a two-electron oxidation of a primary alcohol to the corresponding aldehyde. The active site structure of the inactive form of GO is shown in Figure 1, where two imidazole rings of histidine residues, two phenol moie-

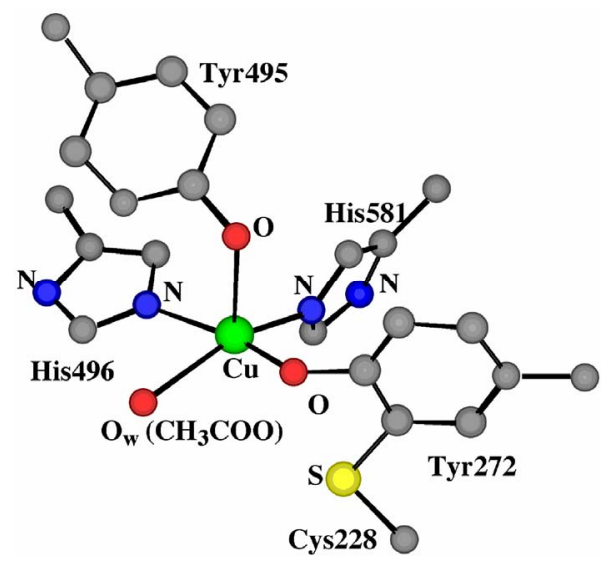

Figure 1. Active site structure of the inactive form of GO.

ties of tyrosine residues, and an acetate ion are coordinated to the copper(II) ion [19].

Conversion to the active form of GO occurs upon one-electron oxidation, since this active form should act as a two-electron oxidant [16-19]. The formal oxidation state of the active form of GO can be described as a $\mathrm{Cu}(\mathrm{III})$-phenolate species. Actually, the active form of GO had been considered to be a copper(III) species [20, 21], but various spectroscopic studies of the active form of GO revealed the formation of the phenoxyl radical species and the $\mathrm{Cu}(\mathrm{II})$-phenoxyl radical bond [22]. The 
free phenoxyl radical is very unstable with the half life estimated to be $2.4 \mu \mathrm{s}$ under ambient conditions, while the $\mathrm{Cu}$ (II)-phenoxyl radical in the active form of GO has a long life; the radical is not quenched for more than one week at room temperature [23]. Thus, properties of the metal coordinated phenoxyl radical show a significant change from those of the free phenoxyl radical.

The valence state difference as expected for one-electron oxidized $\mathrm{Cu}(\mathrm{II})$-phenolate species can be detected in the X-ray crystal structure. For example, the formal oxidation number of the central metal ion of the complexes of iminophenolate dianion, $\left(\mathrm{L}^{\mathrm{AP}}\right)^{2-}$ is not always identical with the experimental valence state $[24,25]$. In the case of $\left[\mathrm{Ni}\left(\mathrm{L}^{\mathrm{AP}}\right)_{2}\right]^{0}$, the formal oxidation state of the central nickel ion is $+\mathrm{IV}$, but the experimental valence state of nickel can be assigned to + II, and two iminophenolate dianions are oxidized to iminosemiquinonate radical anions $\left(\mathrm{L}^{\mathrm{SQ}}\right)^{-}$(Figure 2) [24]. The X-ray structure of this complex revealed that the electronic structure of the ligand is different from that of the free ligand, $\mathrm{H}_{2} \mathrm{~L}^{\mathrm{AP}}$; the $\mathrm{C}-\mathrm{O}$ bond in complexes is shorter and the ortho- $\mathrm{C}-\mathrm{C}$ bonds are longer in comparison to $\mathrm{H}_{2} \mathrm{~L}^{\mathrm{AP}}$, which is assignable to the semiquinonate monoradical. Findings on such an oxidation state difference were reported early in 2000 , though some analogues of this complex had previously been reported [15]. One of the reasons for this may be considered to be that the X-ray structures of a series of these analogues did not show significant geometrical changes of the complexes as a whole. However, subtle ligand structural changes were already pointed out in the previous analyses [25].

This review deals with recent advances in the chemistry related with the oxidation behavior of some metalphenolate complexes and their properties, with emphasis on X-ray crystal structures of metal-phenoxyl radical complexes together with high valent metal-phenolate complexes. In general, the X-ray diffraction method is sometimes difficult for full understanding of the experimental
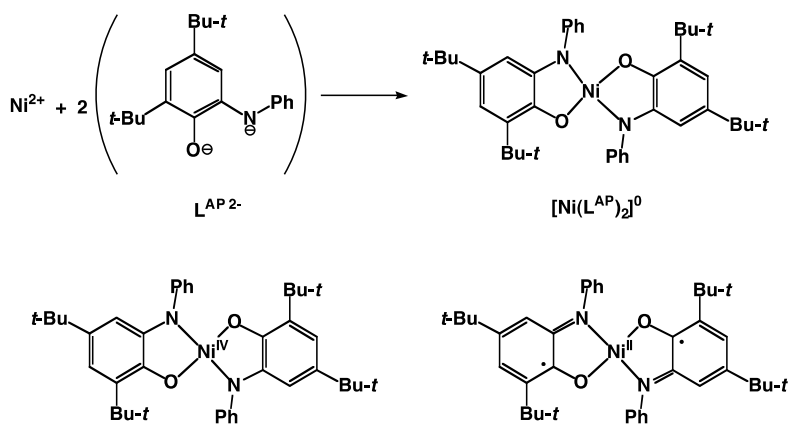

Formal oxidation state: $\left[\mathrm{Ni}^{\mathrm{i}}\left(\mathrm{L}^{\mathrm{AP}}\right)_{2}\right]^{0}$

Experimental oxidation state: $\left[\mathrm{Ni}^{\prime \prime}\left(\mathrm{L}^{\mathrm{SQ}}\right)_{2}\right]^{0}$

Figure 2. An example showing the difference between the experimental oxidation state and the formal oxidation number in the $\mathrm{Ni}$ complexes of iminophenolate dianions, [ $\mathrm{Ni}$ $\left.\left(\mathrm{L}^{\mathrm{AP}}\right)_{2}\right]^{\mathbf{0}}$. valence state and the detailed electronic structure, while the recent high resolution analysis possibly reveals the electronic structures, since the small geometrical change upon oxidation can be detected. This review mainly focuses on the relationship between geometrical and electronic structures of one-electron oxidized metal-phenolate complexes.

\section{Formation of Metal-Phenoxyl Radical Complexes}

Due to the low stability of the uncoordinated free phenoxyl radical, the metal-phenoxyl radical complexes were prepared by one-electron oxidation of the metal-phenolato complexes. The first successful formation of the phenoxyl radical complexes was achieved by chemical and photochemical oxidations of the iron(III)-phenolato complexes (Scheme 1) [26].

This iron-phenoxyl radical complex was stable for more than one year under the dry air at room temperature, and therefore this complex could be isolated as a powder. The oxidants used for generation of the metal-phenoxyl radical species were unstable monoradical species, such as $\mathrm{SO}_{4}{ }^{-}$. Use of more stable chemical reagents and electrochemical oxidation later became popular partly due to easy stochiometric handling. For these methods, determination of the redox potential of the radical formation is important. The tyrosyl radical formation potential by one-electron oxidation of the phenol moiety was reported to be $0.94 \mathrm{~V}$ vs. NHE [27], which is relatively high as compared with the stable metal-centered oxidation potentials such as those for $\mathrm{Fe}^{\mathrm{II}} / \mathrm{Fe}^{\mathrm{III}}$ and $\mathrm{Co}^{\mathrm{II}} / \mathrm{Co}^{\mathrm{III}}$ [28]. The oxidation potentials of the metal coordinated phenolates so far reported are generally lower than those of free phenols, and the potential for generation of the active form of $\mathrm{GO}$ is as low as $0.41 \mathrm{~V}$ [21]. This may be due to the coordination effect of the metal ion. In 1996, Tolman and coworkers reported the $\mathrm{Cu}^{\mathrm{II}}$-phenoxyl radical complexes with similar ligands, which were obtained from the $\mathrm{Cu}^{\mathrm{II}}$-phenolate complexes by electrochemical oxidation and chemical oxidation using oneelectron oxidants such as $\left(\mathrm{NH}_{4}\right)_{2} \mathrm{Ce}\left(\mathrm{NO}_{3}\right)_{6}$ (cerium(IV) ammonium nitrate, CAN) (Scheme 2) [29].

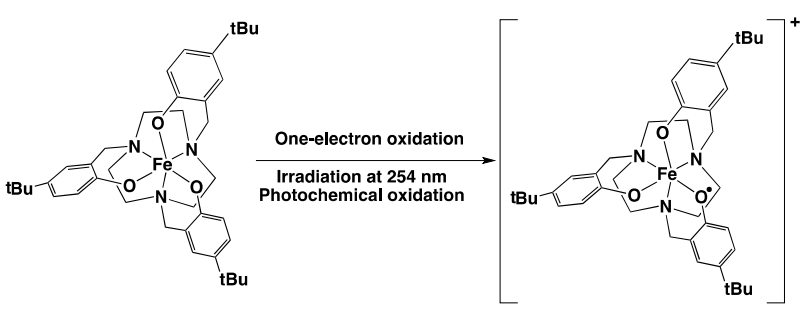

Scheme 1. The iron(III)-phenoxyl radical complex generated by photochemical and chemical oxidations from the iron(III)-phenolate complex. 

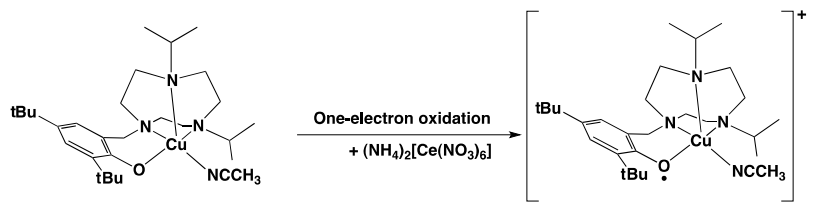

Scheme 2. The copper(II)-phenoxyl radical complex generated by addition of chemical oxidant $\left(\mathrm{NH}_{4}\right)_{2} \mathrm{Ce}\left(\mathrm{NO}_{3}\right)_{6}$ (CAN) from the copper(II)-phenolate complex.

CAN is one of the strong oxidants with the $\mathrm{Ce}^{\mathrm{IV}} / \mathrm{Ce}^{\mathrm{III}}$ potential higher than $1.7 \mathrm{~V}$, which indicates that it can fully oxidize metal-phenolato complexes by one electron to form the corresponding higher valent species [28]. Due to its stability and high potential this oxidant can be used stoichiometrically. On the other hand, CAN is soluble only in relatively polar solvents such as acetone and $\mathrm{CH}_{3} \mathrm{CN}$, and it cannot be used for oxidation of metalphenolato complexes dissolved in $\mathrm{CH}_{2} \mathrm{Cl}_{2}$. In such cases stoichiometric addition of CAN is attained by adding a small volume of an over 10 times more concentrated solution of $\mathrm{CAN}$ in $\mathrm{CH}_{3} \mathrm{CN}$ to the $\mathrm{CH}_{2} \mathrm{Cl}_{2}$ solution of metal-phenoxyl radical complexes. Stack and coworkers reported formation of the radical species by stoichiometric addition of $\mathrm{AgSbF}_{6}$ [30]. This oxidant is soluble in $\mathrm{CH}_{2} \mathrm{Cl}_{2}$, forming silver(0) in the course of oxidation. The oxidation potential of $\mathrm{Ag}^{\mathrm{I}} / \mathrm{Ag}^{0}$ is $0.799 \mathrm{~V}$ vs. NHE, which is higher than the potentials for many metal-coordinated radicals [28,31]. After the reaction, this oxidant can be removed from the reaction mixture by filtration and is therefore useful for in situ crystallization of the metalphenoxyl radical species.

Elelctrochemical oxidation of the metal-phenolate precursors gives the metal-phenoxyl radical complexes [29], but the bulk electrolysis sometimes takes a long time in comparison to the life-time of the oxidized complex. On the other hand, generation of the metal-phenoxyl radical by air-oxidation has been reported [15,32], especially for the complexes of bidentate ligands, such as $o$-aminophenolate and catecholate, to give semiquinonate complexes [15]. However, the air-oxidation method is quite limited due to its low potential for the monodentate phenolate oxidation. Methods based on spontaneous formation of the metal-phenoxyl radical have been reported, formation by disproportionation of the $\mathrm{Cu}(\mathrm{II})$-phenolate species [33, 34] being a unique example.

\section{General Structural Features of Metal-Phenoxyl Radical Complexes}

Free phenoxyl radicals are electron deficient and therefore highly reactive [35]. Even though specific techniques such as flash photolysis or pulsed radiolysis have been successfully used for detection of phenoxyl radicals, simple phenoxyl radicals are rather uncommon due to their low stability. Stabilization of the phenoxyl radicals has been attained by substitution of functional groups in the ortho- and para-positions. The spin density of the radical electron on the phenoxyl radical species was estimated to be significantly high in ortho- and para-positions. For understanding the electronic structure of the phenoxyl radical, the canonical presentation of phenoxyl radical is useful, as shown in Scheme 3. The canonical forms are reflected in the crystal structures of metal-phenoxyl radical complexes. The $\mathrm{C}-\mathrm{O}$ bond length of the phenoxyl radical complexes becomes shorter and the ortho-C-C bonds are longer in comparison to the phenolate moiety. Further, $\pi$-electron donating substituents, such as the methoxy group, in ortho- and para-positions also stabilize the phenoxyl radical, whose quinoid character is emphasized [36]. On the other hand, the metal-oxygen bond of the phenoxyl radical is longer than that of the metal-phenolate due to the electron deficiency of the phenoxyl radical. However, some of the phenoxyl radical complexes show the shortening of the metal-oxygen bond length of the phenoxyl radical as a result of delocalization of the unpaired electron (vide infra). In this case, no significant radical structural feature is shown in the crystal structure.

Difference between metal-centered oxidation and metalphenoxyl radical species can be detected in X-ray crystal structures. The metal-oxygen bond lengths of high-valent metal-phenolate complexes are shorter than those before oxidation, which is different from the characteristic of meta-phenoxyl radical complexes. The high-valent metalphenolate complexes should have "phenolate" moieties, so that the structural change of the phenolate moiety is rather small in comparison to the phenoxyl radical complexes [37].

\section{Crystal Structures of Metal-Phenoxyl Radical Complexes}

\subsection{Cr(III)-Phenoxyl Radical Complex}

Recently, X-ray crystal structures of some of the metalphenoxyl radical species have been reported, while the examples are still limited [37]. The crystal structures exhibit a geometry similar to those of the complexes before oxidation, but their details are different. Thus, the $\mathrm{C}-\mathrm{C}$ and $\mathrm{C}-\mathrm{O}$ bond lengths of the phenoxyl moiety were revealed to be different from the corresponding values of the phenolate complexes. The octahedral chromium(III) complex has a $\mathrm{d}^{3}$ configuration and half-filled $\mathrm{t}_{2 \mathrm{~g}}$ orbital in the central metal ion, so that the $\mathrm{Cr}^{\mathrm{III}}$ ion is paramag-

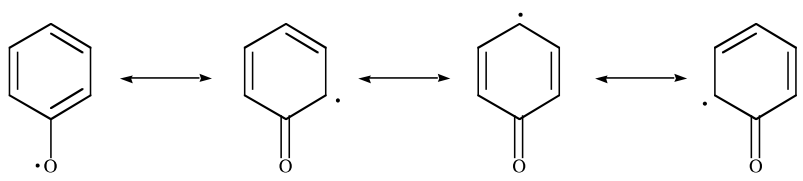

Scheme 3. Canonical forms of phenoxyl radical. 
netic and redox innocent in the classical potential range. The $\mathrm{Cr}^{\mathrm{III}}$-phenoxyl radical complex having a three phenolate moieties connected with the triazacyclononane backbone is the first example of the metal-monodentate phenoxyl radical complex revealed by the X-ray crystal structure analysis (Figure 3) [38]. The crystal structure of this complex having a $p$-methoxyphenoxyl radical shows a quinoid distribution of the bond lengths in the phenoxyl ring, as observed in the structure of the tri(alkyl)phenoxyl radical. As expected, the $\mathrm{Cr}-\mathrm{O}_{\text {phenoxyl }}$ bond is weakened in comparison with the other phenolate moieties in this complex. Therefore, this complex is a relatively localized radical complex, which can be described as $\left[\mathrm{Cr}(\text { phenoxyl })(\text { phenolate })_{2}\right]^{+}$. However, no X-ray crystal structures of the other metal complexes having this ligand and its analogues have been reported yet.

\subsection{Crystal Structure of Cu-Phenoxyl Radical Complex}

The first example of X-ray crystal structural analysis of the $\mathrm{Cu}^{\mathrm{II}}$-phenoxyl radical complex shown in Figure 4 has a relatively localized structure with one of the two phenolate moieties oxidized to the phenoxyl radical $[39,40]$. The two $\mathrm{C}-\mathrm{C}$ bonds involving the $\mathrm{C}-\mathrm{O}$ moiety in the radical are $0.03-0.04 \AA$ longer and the $\mathrm{C}-\mathrm{O}$ bond is ca. $0.06 \AA$ shorter than the corresponding bonds in the phenolate moiety. The two $\mathrm{Cu}-\mathrm{O}$ bond lengths are also different, the bond length for the phenoxyl radical being longer in comparison to the $\mathrm{Cu}$-phenolate bond. Such characteristics are in good agreement with the corresponding structural features of the metal-phenoxyl radical complexes. Therefore, this complex has a localized electronic structure described as $\mathrm{Cu}^{\text {II }}$ (phenolate) (phenoxyl radical). Other metal complexes having this ligand, such as cobalt(II) and zinc(II) complexes, have also been reported. The $\mathrm{Zn}$ and Co complexes showed structural characteristics similar to those of this copper complex, indicating that they can also be assigned to the localized phenoxyl radical complexes, $\left[\mathrm{M}^{\mathrm{II}}\right.$ (phenolate)(phenoxyl radical) $]^{+}$. However, X-ray crystal structure analysis of the Co(II)-phenoxyl radical complex has not been reported yet [41].

\section{Structures of One-Electron Oxidized Metal(II)-Shiff Base Complexes}

\subsection{Group 10 Metal Salen-Type Complexes $($ Metal $=$ Ni(II), Pd(II) and Pt(II))}

The X-ray crystal structure analyses of one-electron oxidized group 10 metal salen-type complexes are shown in Figure 5 [42-44]. The crystal structures of all these complexes were found to be similar to those of the corresponding complexes before oxidation, which supports the $\mathrm{CV}$ results that significant structure changes did not occur in the course of the oxidation.

However, a close look into the details of the structures

\section{(A)}

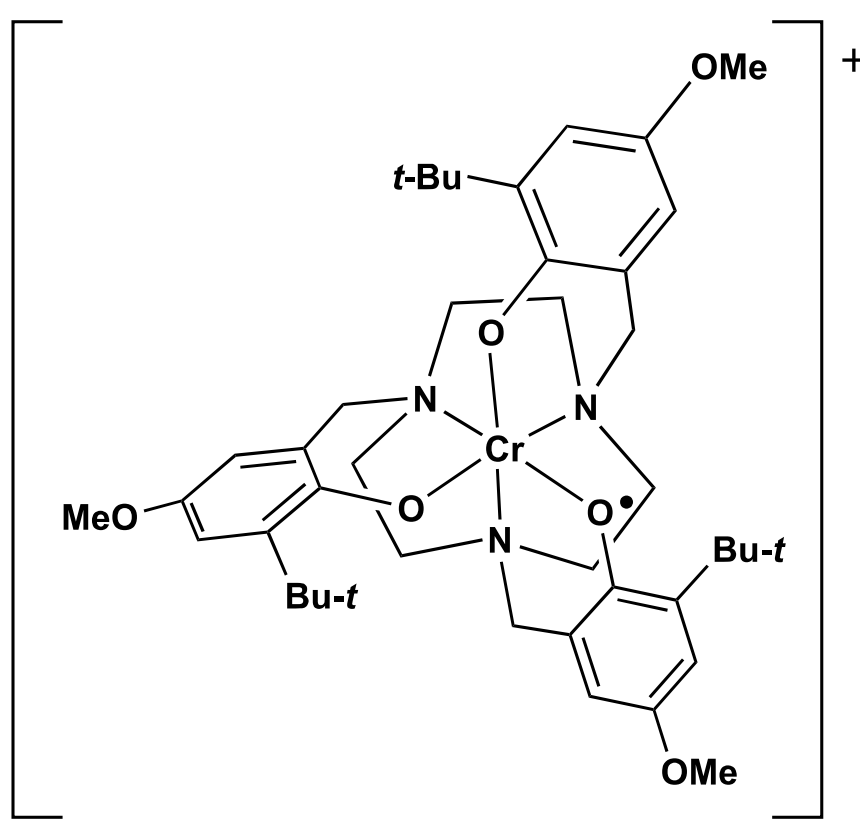

(B)

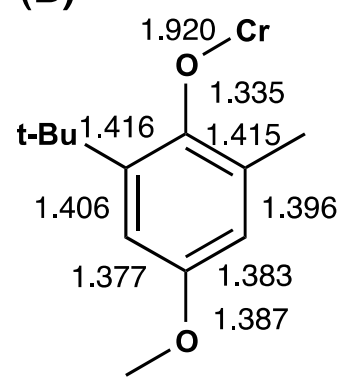

(C)

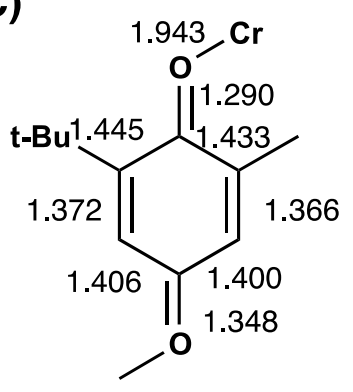

Figure 3. Molecular structure and selected bond lengths of the first metal-phenoxyl radical complex based on the $\mathrm{X}$-ray crystal structure analysis; (A) molecular structure of the phenoxyl radical complex; (B), (C) Selected bond lengths of the phenolate $(B)$ and phenoxyl radical $(C)$ in the first phenoxyl radical complex based on the $X$-ray crystal structure analysis. 
(A)

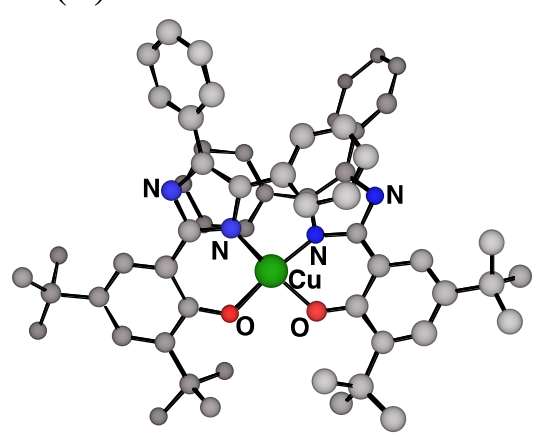

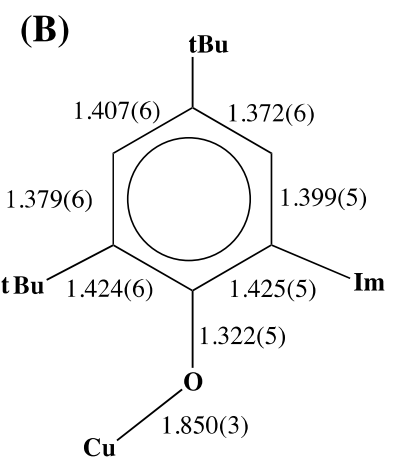

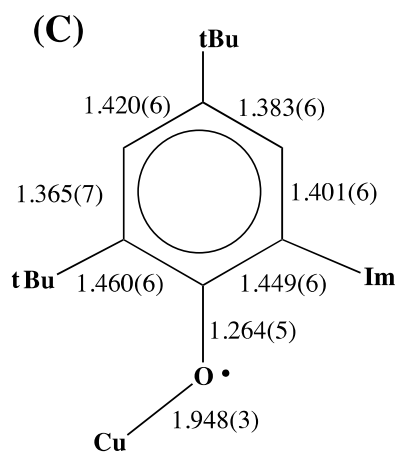

(D)
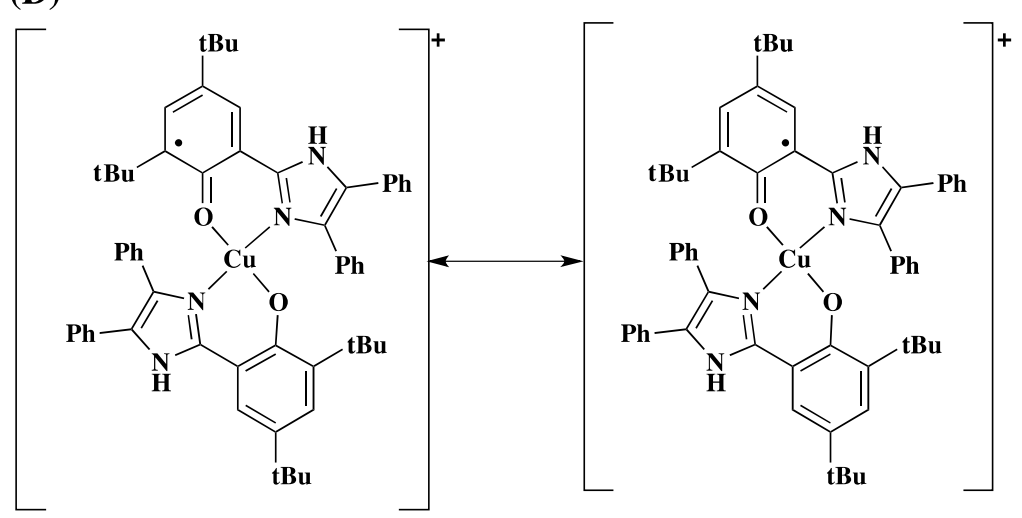

Figure 4. First example of the crystal structure of the $\mathrm{Cu}^{\mathrm{II}}$-phenoxyl radical complex. (A) crystal structure of the complex; (B), (C) Selected bond lengths of the phenolate ligand (B) and phenoxyl radical ligand (C) in the first $\mathrm{Cu}$-phenoxyl radical complex based on the X-ray crystal structure analysis; (D) Canonical structures of the complex.

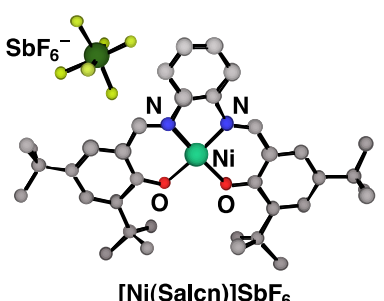

$\left[\mathrm{Ni}(\right.$ Salcn) $] \mathrm{SbF}_{6}$

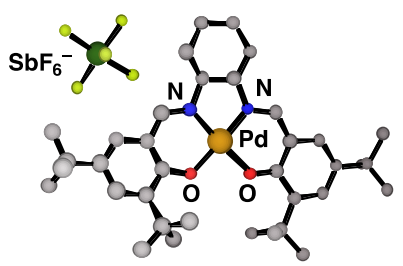

[Pd(Salcn) $] \mathrm{SbF}_{6}$

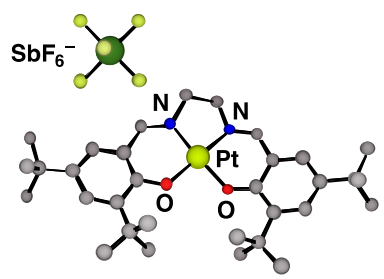

[Pt(Salen)]SbF 6

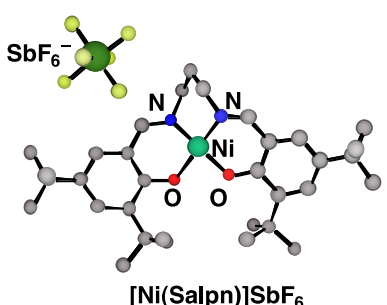

$\left[\mathrm{Ni}(\right.$ Salpn) $] \mathrm{SbF}_{6}$

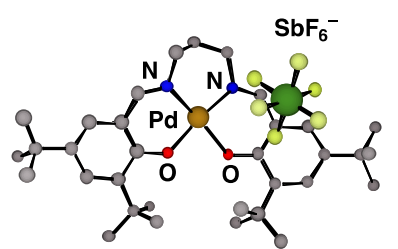

$\left[\mathrm{Pd}(\right.$ Salpn) $] \mathrm{SbF}_{6}$

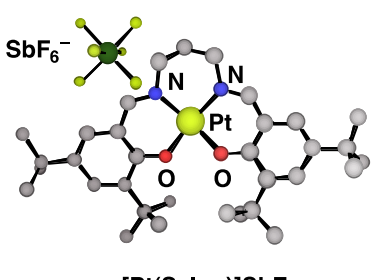

[Pt(Salpn)]SbF 6

Figure 5. Ball and stick views of crystal structures of oneelectron oxidized group 10 metal salen-type complexes. reveals that there are subtle differences between them, and especially the oxidized $\mathrm{Pd}(\mathrm{II})$ complexes are different from the other complexes [43]. Comparison of the 5-membered dinitrogen chelate backbones of the Salcn and Salen complexes indicates that upon oxidation the $\mathrm{Ni}$ and $\mathrm{Pt}$ complexes exhibited a clear coordination sphere contraction due to shortening of the $\mathrm{M}-\mathrm{O}$ and $\mathrm{M}-\mathrm{N}$ bond lengths (Table 1) [42,43]. On the other hand, the $\mathrm{Pd}$ complex showed an unsymmetrical contraction: One of the Pd-O bonds (2.003 $\AA$ ) is longer than the other (1.963 $\AA$ ), and the C-O bond (1.263 $\AA$ ) of the phenolate moiety with the longer Pd-O bond is shorter than the other $\mathrm{C}-\mathrm{O}$ bond $(1.318 \AA)$. The phenolate moiety with a shorter $\mathrm{C}-\mathrm{O}$ bond length shows the lengthening of the ring ortho $\mathrm{C}-\mathrm{C}$ bonds in comparison with the other $\mathrm{C}-\mathrm{C}$ bonds (Table 1). These structural features of the phenolate moiety in the oxidized $\mathrm{Pd}$ complex are in good agreement with the characteristics of the phenoxyl radical, which is in the quinoid form due to delocalization of the radical electron on the phenoxyl ring as shown in Scheme 3. Such properties were also detected for the Pd complex with a 6-membered dinitrogen chelate back bone, $[\operatorname{Pd}(\mathbf{S a l p n})]$ $\mathrm{SbF}_{6}$ [44]. In addition, the $\mathrm{SbF}_{6}^{-}$counterion was positioned close to the quinoid moiety of this complex; the closest distance between the $\mathrm{SbF}_{6}^{-}$and the $\mathrm{C}-\mathrm{O}$ carbon atom of the phenoxyl ligand was $3.026 \AA$. Therefore, 
Table 1. Comparison of the M-O and M-N, and C-C and C-O bond lengths $(\AA)$ in the phenolate moieties of the oxidized group 10 metal salen type complexes having a 5-membered dinitrogen chelate backbone.

\begin{tabular}{|c|c|c|c|c|c|}
\hline & & {$[\mathrm{Ni}(\mathrm{Salcn})] \mathrm{SbF}_{6}$} & {$[\mathrm{Ni}(\text { salen })]_{2} \mathrm{O}^{a}$} & {$[\mathrm{Pd}($ Salcn $)] \mathrm{SbF}_{6}$} & {$[\mathrm{Pt}($ Salen $)] \mathrm{SbF}_{6}$} \\
\hline & M-O & $\begin{array}{l}1.827(3) \\
1.830(4)\end{array}$ & $\begin{array}{l}1.912(2) \\
1.938(2)\end{array}$ & $\begin{array}{l}2.003(4) \\
1.963(4)\end{array}$ & $\begin{array}{l}1.971(6) \\
1.989(6)\end{array}$ \\
\hline & $\mathrm{M}-\mathrm{N}$ & $\begin{array}{l}1.825(4) \\
1.843(4)\end{array}$ & $\begin{array}{l}2.108(3) \\
2.130(3)\end{array}$ & $\begin{array}{l}1.943(5) \\
1.942(5)\end{array}$ & $\begin{array}{l}1.933(7) \\
1.922(8)\end{array}$ \\
\hline & $\mathrm{O}-\mathrm{C}_{1}$ & $\begin{array}{l}1.299(6) \\
1.302(6)\end{array}$ & $\begin{array}{l}1.315(4) \\
1.310(4)\end{array}$ & $\begin{array}{l}1.263(7) \\
1.318(7)\end{array}$ & $\begin{array}{c}1.309(9) \\
1.299(10)\end{array}$ \\
\hline $\mathrm{N}-\mathrm{C}_{7}$ & $\mathrm{C}_{1}-\mathrm{C}_{2}$ & $\begin{array}{l}1.448(7) \\
1.439(7)\end{array}$ & $\begin{array}{l}1.413(5) \\
1.412(5)\end{array}$ & $\begin{array}{l}1.473(8) \\
1.443(7)\end{array}$ & $\begin{array}{c}1.44(1) \\
1.459(10)\end{array}$ \\
\hline $\mathrm{O}-\mathrm{C}_{1}$ & $\mathrm{C}_{2}-\mathrm{C}_{3}$ & $\begin{array}{l}1.380(8) \\
1.362(7)\end{array}$ & $\begin{array}{l}1.378(5) \\
1.376(5)\end{array}$ & $\begin{array}{l}1.382(9) \\
1.373(9)\end{array}$ & $\begin{array}{c}1.377(10) \\
1.39(1)\end{array}$ \\
\hline $\mathrm{C}_{2}-\mathrm{C}_{3}$ & $\mathrm{C}_{3}-\mathrm{C}_{4}$ & $\begin{array}{l}1.399(8) \\
1.412(7)\end{array}$ & $\begin{array}{l}1.386(6) \\
1.405(6)\end{array}$ & $\begin{array}{l}1.386(9) \\
1.414(9)\end{array}$ & $\begin{array}{l}1.44(1) \\
1.38(1)\end{array}$ \\
\hline & $\mathrm{C}_{4}-\mathrm{C}_{5}$ & $\begin{array}{l}1.383(7) \\
1.382(8)\end{array}$ & $\begin{array}{l}1.373(6) \\
1.372(6)\end{array}$ & $\begin{array}{l}1.395(9) \\
1.371(8)\end{array}$ & $\begin{array}{l}1.38(1) \\
1.40(1)\end{array}$ \\
\hline & $\mathrm{C}_{5}-\mathrm{C}_{6}$ & $\begin{array}{l}1.405(7) \\
1.388(8)\end{array}$ & $\begin{array}{l}1.411(5) \\
1.408(5)\end{array}$ & $\begin{array}{l}1.393(9) \\
1.398(9)\end{array}$ & $\begin{array}{c}1.409(10) \\
1.41(1)\end{array}$ \\
\hline & $\mathrm{C}_{6}-\mathrm{C}_{1}$ & $\begin{array}{l}1.424(7) \\
1.437(7)\end{array}$ & $\begin{array}{l}1.423(5) \\
1.427(5)\end{array}$ & $\begin{array}{l}1.470(8) \\
1.426(8)\end{array}$ & $\begin{array}{l}1.44(1) \\
1.43(1)\end{array}$ \\
\hline
\end{tabular}

${ }^{a}$ The bond lengths are described for one of the two salen units of the molecule.

one-electron oxidized Pd(II) complexes can be assigned to relatively localized $\mathrm{Pd}^{\mathrm{II}}$ (phenoxyl)(phenolate) complexes.

However, a close look into the details of the structures reveals that there are subtle differences between them, and especially the oxidized $\mathrm{Pd}(\mathrm{II})$ complexes are different from the other complexes [43]. Comparison of the 5 -membered dinitrogen chelate backbones of the Salcn and Salen complexes indicates that upon oxidation the $\mathrm{Ni}$ and $\mathrm{Pt}$ complexes exhibited a clear coordination sphere contraction due to shortening of the $\mathrm{M}-\mathrm{O}$ and $\mathrm{M}-\mathrm{N}$ bond lengths (Table 1) $[42,43]$. On the other hand, the Pd complex showed an unsymmetrical contraction: One of the Pd-O bonds $(2.003 \AA)$ is longer than the other $(1.963$ $\AA$ ), and the C-O bond (1.263 $\AA$ ) of the phenolate moiety with the longer Pd-O bond is shorter than the other $\mathrm{C}-\mathrm{O}$ bond (1.318 $\AA$ ). The phenolate moiety with a shorter C-O bond length shows the lengthening of the ring ortho $\mathrm{C}-\mathrm{C}$ bonds in comparison with the other $\mathrm{C}$-C bonds (Table 2). These structural features of the phenolate moiety in the oxidized Pd complex are in good agreement with the characteristics of the phenoxyl radical, which is in the quinoid form due to delocalization of the radical electron on the phenoxyl ring as shown in Scheme 3. Such properties were also detected for the Pd complex with a 6-membered dinitrogen chelate back bone, $[\operatorname{Pd}(\mathbf{S a l p n})]$ $\mathrm{SbF}_{6}$ [44]. In addition, the $\mathrm{SbF}_{6}^{-}$counterion was positioned close to the quinoid moiety of this complex; the closest distance between the $\mathrm{SbF}_{6}^{-}$and the C-O carbon atom of the phenoxyl ligand was $3.026 \AA$. Therefore, one-electron oxidized Pd(II) complexes can be assigned to relatively localized $\mathrm{Pd}^{\mathrm{II}}$ (phenoxyl)(phenolate) complexes.
The Ni and Pt 5-membered dinitrogen chelate complexes also exhibited a clear symmetrical coordination sphere contraction in both the two M-O and two M-N bond lengths (ca. $0.02 \AA$ ) upon oxidation, and the $\mathrm{C}-\mathrm{O}$ bond distances of these complexes are also shorter than the same bonds before oxidation. These observations suggest that the complexes have the phenoxyl radical characteristics and that the radical electron is delocalized on the two phenolate moieties. Indeed, the XPS and K-edge XANES of an oxidized Ni complex showed the same binding energies and pre-edge peak of the nickel ion as those of the complex before oxidation $[42,43,45]$. These results supported that the valence state of the nickel ion is +II. On the other hand, $\mathrm{Ni}^{\mathrm{III}}$ complexes of salen-type ligands can be generated by the axial ligand coordination to the oxidized nickel complex. The X-ray crystal structure of the $\mathrm{Ni}^{\text {III }}$-salen-type complex, [Ni (salen) $]_{2} \mathrm{O}$, was reported in 2000 by Mitra et al. (Figure 6 and Table 1) [46]. The $\mathrm{Ni}^{\mathrm{III}}$ complex was a dinuclear species bridged by an oxo group with a 5-coordinated square pyramidal structure around each $\mathrm{Ni}^{\mathrm{III}}$ ion. The $\mathrm{Ni}$ oxo bond is short $(1.790(2) \AA$ ), while the Ni-phenolate oxygen bonds (1.912 - $1.949 \AA)$ are similar to those of the $\mathrm{Ni}^{\mathrm{iI}}$ salen-type complexes. Further the $\mathrm{C}-\mathrm{O}$ and $\mathrm{C}-\mathrm{C}$ bond lengths of phenolate moieties in the $\mathrm{Ni}^{\mathrm{III}}$ complex are also similar to those of the $\mathrm{Ni}^{\mathrm{II}}$ salen-type complexes, suggesting that the oxidation locus of this complex is assigned to the metal center rather than the phenolate moiety. Thus, the high-valent $\mathrm{Ni}^{\mathrm{III}}$-phenolate complexes have different structural features from those of the $\mathrm{Ni}^{\mathrm{II}}$ phenoxyl radical complexes.

However, a close look into the details of the crystal structures reveals that there are subtle differences be- 
Table 2. Selected bond lengths $(\AA)$ of the group 10 metal 6-membered dinitrogen chelate complexes, M(Salpn) and [M(Salpn) $]^{+}$ complexes.

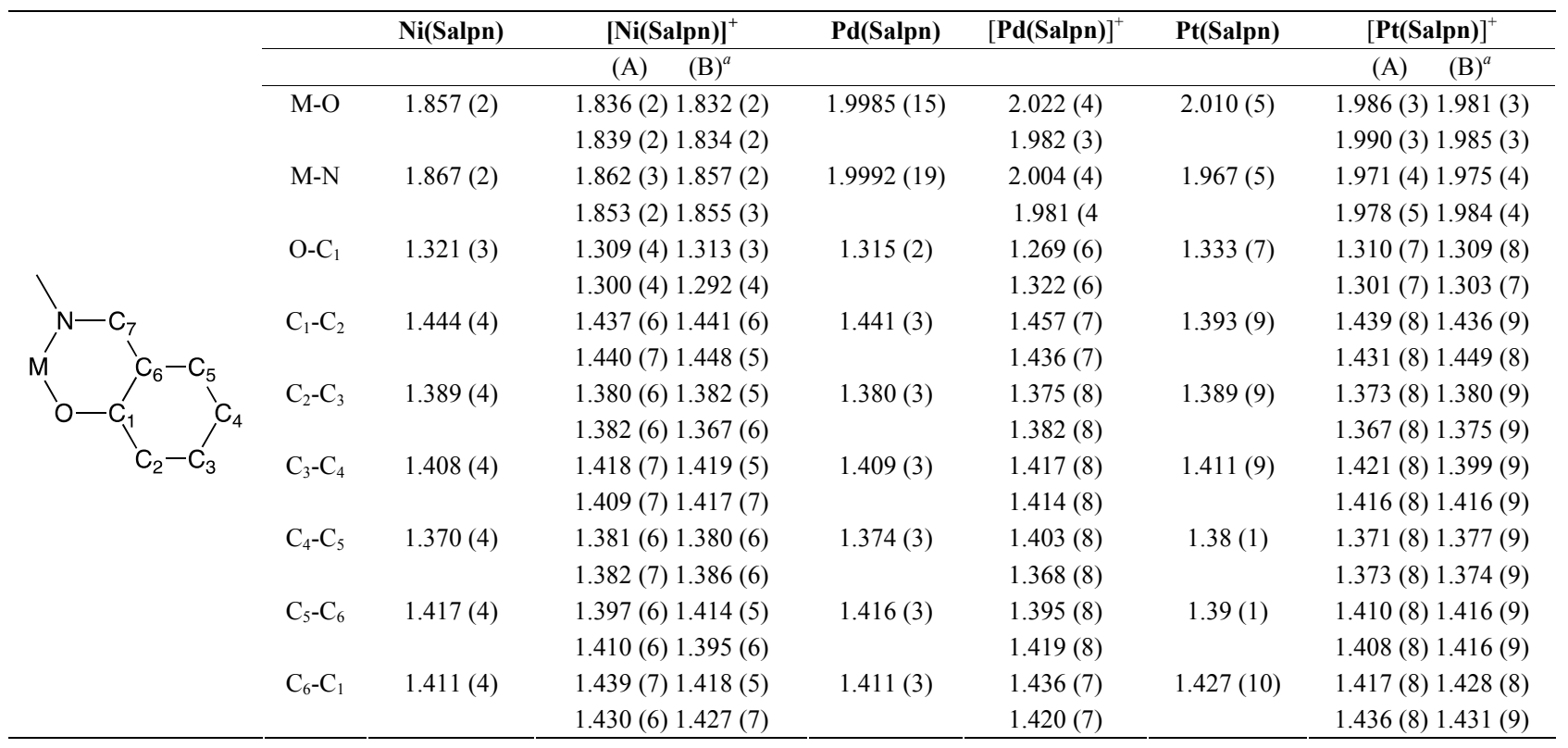

${ }^{a}(\mathrm{~A})$ and (B) indicates the bond lengths of the two independent molecules (A) and (B) in the unit cell.

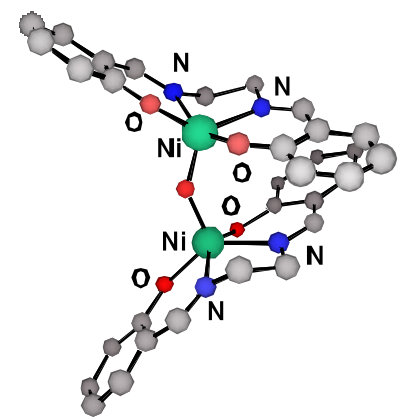

Figure 6. Crystal structure of oxo-bridged dinuclear Ni(III) complex, $[\mathrm{Ni}(\text { salen })]_{2} \mathrm{O}$.

tween them, and especially the oxidized Pd(II) complexes are different from the other complexes $[42,43]$. Comparison of the 5-membered dinitrogen chelate backbones of the Salcn and Salen complexes indicates that upon oxidation the $\mathrm{Ni}$ and $\mathrm{Pt}$ complexes exhibited a clear coordination sphere contraction due to shortening of the $\mathrm{M}-\mathrm{O}$ and $\mathrm{M}-\mathrm{N}$ bond lengths. On the other hand, the Pd complex showed an unsymmetrical contraction [42]: One of the Pd-O bonds $(2.003 \AA)$ is longer than the other $(1.963 \AA)$, and the $\mathrm{C}-\mathrm{O}$ bond $(1.263 \AA)$ of the phenolate moiety with the longer Pd-O bond is shorter than the other $\mathrm{C}$-O bond $(1.317 \AA)$. The phenolate moiety with a shorter $\mathrm{C}-\mathrm{O}$ bond length has the lengthening of the ring ortho C-C bonds in comparison with those of the other one. These structural features of the phenolate moiety in the oxidized Pd complex are in good agreement with the characteristics of the phenoxyl radical, which showed the quinoid form due to delocalization of the radical electron on the phenolate moiety as shown in Scheme 2 and reference [53]. Such properties were also detected for the Pd complex with the 6-membered dinitrogen chelate back bone, $[\mathrm{Pd}(\mathrm{Salpn})] \mathrm{SbF}_{6}$ [43]. In addition, the $\mathrm{SbF}_{6}^{-}$counterion was positioned close to the quinoid moiety of this complex; the closest distance between the $\mathrm{SbF}_{6}^{-}$and the $\mathrm{C}-\mathrm{O}$ carbon atom of the phenoxyl ligand was $3.026 \AA$. Therefore, one-electron oxidized $\mathrm{Pd}(\mathrm{II})$ complexes can be assigned to relatively localized $\mathrm{Pd}^{\mathrm{II}}$ (phenoxyl)(phenolate) complexes.

In the case of Pt complexes, the XPS of the oxidized complex was slightly different from that before oxidation. The binding energies of the Pt ion in the oxidized complex were $+0.2 \mathrm{eV}$ higher, and $\mathrm{L}_{\mathrm{III}}$-edge XANES exhibited an increasing white line. Such spectral features suggest that the oxidation state of the $\mathrm{Pt}$ ion in the oxidized complex is higher than $+\mathrm{II}$ but that the differences are rather small [45]. From these results, $[\mathrm{Pt}(\mathbf{S a l e n})] \mathrm{SbF}_{6}$ can be described mainly as the Pt(II)-phenoxyl radical species, but the radical electron is fully delocalized over the whole molecule including the central metal ion [43]. Such an electronic structure is similar to that of [Ni (Salcn) $] \mathrm{SbF}_{6}$, and therefore, the X-ray structure of [Pt (Salen) $\mathrm{SbF}_{6}$ does not show significantly different characteristics from those of $[\mathrm{Ni}(\mathbf{S a l c n})] \mathrm{SbF}_{6}$.

The six-membered $\mathrm{Ni}^{\mathrm{II}}$ and $\mathrm{P}^{\mathrm{II}}$ Salpn chelate complexes are slightly different from the 5-membered dinitrogen chelate Salen and Salen complexes [44]. The crystal structures of both oxidized Salpn complexes exhibited two crystallographically independent molecules in the unit cell, where the $\mathrm{M}-\mathrm{O}$ and $\mathrm{M}-\mathrm{N}$ bond lengths do 
not differ substantially between the two molecules. The bond lengths in the coordination plane are ca. $0.02 \AA$ shorter than those of the neutral complexes, and this contraction upon oxidation is in good agreement with that in the 5-membered dinitrogen chelate complexes (Table 2). However, the $\mathrm{C}-\mathrm{O}$ bond lengths of the two phenolate moieties differed for the two independent molecules; one of the molecules showed very similar $\mathrm{C}-\mathrm{O}$ bond lengths, while the bond lengths in the other molecule were slightly different, showing a similar tendency to that of the oxidized Pd complexes (Table 2). Therefore, the 6-membered chelate $\mathrm{Ni}$ and $\mathrm{Pt}$ complexes can be considered to be closer to the localized phenoxyl radical metal (II) complexes in comparison with the 5-membered chelate complexes of Salcn and Salen due to the chelate effect of the dinitrogen backbone. Such characteristics of the more localized radical electron in oxidized $\mathrm{Ni}^{\mathrm{II}}$ and $\mathrm{Pt}^{\mathrm{II}}$ Salpn complexes are also observed in the spectroscopies [47], which indicate that the X-ray structures reflect the electronic structures of the complexes.

\section{2. $\mathrm{Cu}$ (II)-Salen-Type Complexes.}

The electronic structure determinations of the $\mathrm{Cu}$ complexes are clearly made by X-ray structure analyses. Structures of four one-electron oxidized $\mathrm{Cu}^{\mathrm{II}}$ salen-type complexes are shown in Figure 7 [48-51]. X-ray analyses of all these complexes established that their structures are similar to those before oxidation, indicating a simple one-electron transfer from the precursors. However, these $\mathrm{Cu}$ complexes have different electronic structures.

Figure 7 shows that the oxidized $\mathrm{Cu}$ (II) complexes have the $\mathrm{SbF}_{6}^{-}$counterion at different positions. The crystal structure of the 5-membered chelate dinitrogen backbone complex, $[\mathrm{Cu}(\mathbf{1}, \mathbf{2}-\mathrm{Salcn})] \mathrm{SbF}_{6}$, indicates that a weak axial $\mathrm{Cu}-\mathrm{F}$ interaction $(2.76 \AA)$ exists between the counterion and the metal center [48]. The position of counteranion suggests that $[\mathrm{Cu}(\mathbf{1}, \mathbf{2}-\mathrm{Salcn})] \mathrm{SbF}_{6}$ has a $\mathrm{Cu}^{\mathrm{III}}$ character. In addition this complex showed contraction of the coordination sphere without shortening of the $\mathrm{C}-\mathrm{O}$ bonds of both phenolate moieties, and distortion of the coordination plane was substantially reduced from that in $\mathrm{Cu}(\mathbf{1 , 2 - S a l c n})$. Such structural features are in good agreement with those of the low-spin $\mathrm{d}^{8} \mathrm{Cu}$ (III) complexes. Indeed, the XAF and XPS studies of $[\mathrm{Cu}$ (1,2-Salcn) $] \mathrm{SbF}_{6}$ revealed the $\mathrm{Cu}(\mathrm{III})$-phenolate ground state [48]. On the other hand, the 6-membered chelate dinitrogen salen-type complex, $[\mathrm{Cu}(\mathbf{1}, \mathbf{3}-\mathrm{Salcn})] \mathrm{SbF}_{6}$, showed a weak interaction between the counterion and one side of the phenolate moieties, suggesting that this complex can be assigned to the $\mathrm{Cu}^{\mathrm{II}}$-phenoxyl radical [49]. This complex shows that the C-O bond of one of the phenolate moieties is shortened and that the $\mathrm{Cu}-\mathrm{O}$ bond with the shortened phenolate moiety becomes longer (Table 3). The counterion is close to the phe-
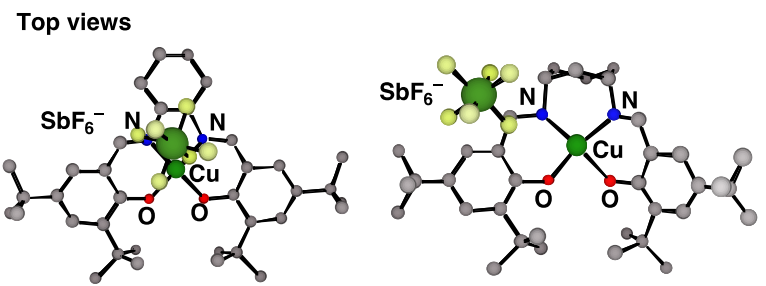

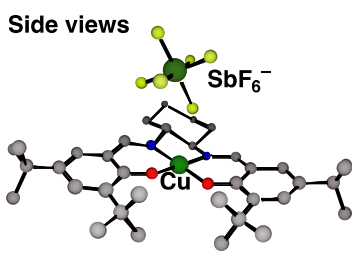

$[\mathrm{Cu}(1,2-\mathrm{Salcn})] \mathrm{SbF}_{6}$

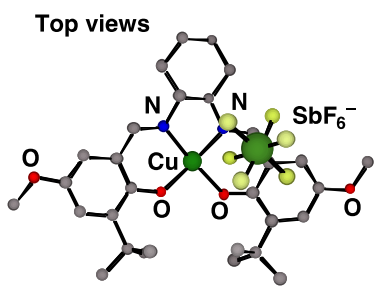

Side views

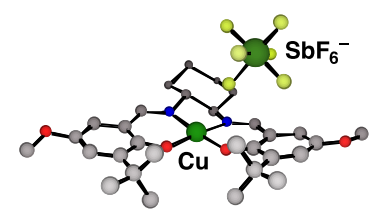

$[\mathrm{Cu}(\mathrm{MeO}-\mathrm{Salcn})] \mathrm{SbF}_{6}$

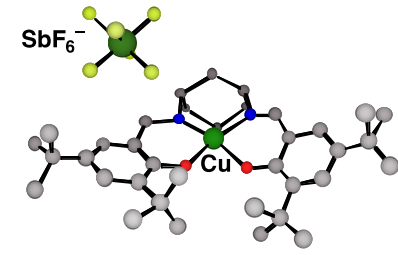

$[\mathrm{Cu}(1,3-\mathrm{Salcn})] \mathrm{SbF}_{6}$
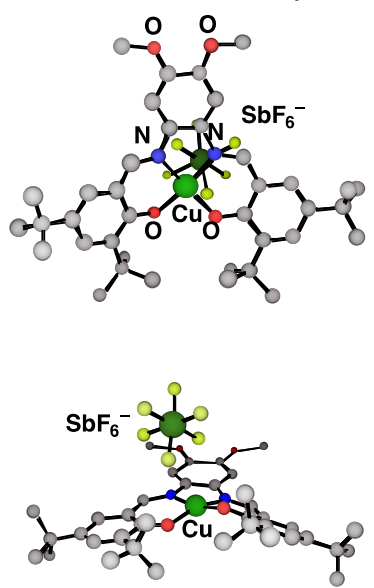

[Cu(Salphen-OMe) $] \mathrm{SbF}_{6}$
Figure 7. Crystal structures of one-electron oxidized $\mathrm{Cu}(\mathrm{II})$ salen-type complexes.

nolate moiety of the shortened C-O bond. These features correspond well with those of the oxidized $\operatorname{Pd}($ Salpn $)$ complex having a relatively localized $\mathrm{Pd}^{\mathrm{II}}$ (phenoxyl) (phenolate) structure. The localized electronic structure of this complex is inferred to be maintained in solution from the results of various spectroscopic methods. Such structural characteristics are also observed for $[\mathrm{Cu}(\mathbf{M e O}-$ Salcn) $\mathrm{SbF}_{6}$ [50]. One of the phenolate moieties in $[\mathrm{Cu}$ (MeO-Salcn) $] \mathrm{SbF}_{6}$ showed the quinoid structural feature, the two $\mathrm{C}-\mathrm{O}$ bonds between the carbon and oxygen atoms of the two phenolate moieties being shorter in comparison to those of the species before oxidation, $\mathrm{Cu}$ (MeO-Salcn). These results suggest that the small structural differences caused by chelate ring size and substitution in the phenolate ring lead to different electronic structures in the one-electron oxidized salen-type $\mathrm{Cu}^{\mathrm{II}}$ complexes.

The other one-electron oxidized complex, $[\mathrm{Cu}(\mathbf{S a l}-$ phen-OMe) $] \mathrm{SbF}_{6}$, has a different electronic structure from the previous three salen-type complexes. The C-C and $\mathrm{C}-\mathrm{O}$ bond lengths within the phenolate rings do not differ 
Table 3. Selected bond lengths $(\AA)$ of the oxidized $\mathrm{Cu}$ complexes.

\begin{tabular}{|c|c|c|c|c|c|}
\hline & & {$[\mathrm{Cu}(1,2-\text { Salen })]^{+}$} & {$[\mathrm{Cu}(1,3-\text { Salen })]^{+}$} & {$[\mathrm{Cu}(\mathrm{MeO}-\mathrm{Salen})]^{+}$} & {$[\mathrm{Cu}(\text { Saophen-OMe })]^{+}$} \\
\hline & $\mathrm{Cu}-\mathrm{O}_{1}$ & $\begin{array}{l}1.831(6) \\
1.838(6)\end{array}$ & $\begin{array}{l}1.996(3) \\
1.912(3)\end{array}$ & $\begin{array}{l}1.934(3) \\
1.861(3)\end{array}$ & $\begin{array}{l}1.869(3) \\
1.896(3)\end{array}$ \\
\hline & $\mathrm{Cu}-\mathrm{N}_{1}$ & $\begin{array}{l}1.877(6) \\
1.880(6)\end{array}$ & $\begin{array}{l}2.006(4) \\
1.963(4)\end{array}$ & $\begin{array}{l}1.928(3) \\
1.916(3)\end{array}$ & $\begin{array}{l}1.921(3) \\
1.920(3)\end{array}$ \\
\hline$N$ & $\mathrm{O}_{1}-\mathrm{C}_{1}$ & $\begin{array}{c}1.317(10) \\
1.317(9)\end{array}$ & $\begin{array}{l}1.266(5) \\
1.304(5)\end{array}$ & $\begin{array}{l}1.250(5) \\
1.311(5)\end{array}$ & $\begin{array}{l}1.300(5) \\
1.304(4)\end{array}$ \\
\hline$v_{0}$ & $\mathrm{C}_{1}-\mathrm{C}_{2}$ & $\begin{array}{l}1.438(12) \\
1.446(11)\end{array}$ & $\begin{array}{c}1.464(6) \\
1.43(6)\end{array}$ & $\begin{array}{l}1.478(5) \\
1.421(5)\end{array}$ & $\begin{array}{l}1.438(6) \\
1.435(5)\end{array}$ \\
\hline $\mathrm{O}_{1}$ & $\mathrm{C}_{2}-\mathrm{C}_{3}$ & $\begin{array}{l}1.391(11) \\
1.375(12)\end{array}$ & $\begin{array}{l}1.368(6) \\
1.378(6)\end{array}$ & $\begin{array}{l}1.345(6) \\
1.381(6)\end{array}$ & $\begin{array}{l}1.367(6) \\
1.364(5)\end{array}$ \\
\hline $\mathrm{C}_{2}-\mathrm{C}_{3}$ & $\mathrm{C}_{3}-\mathrm{C}_{4}$ & $\begin{array}{l}1.400(12) \\
1.429(12)\end{array}$ & $\begin{array}{l}1.413(6) \\
1.412(7)\end{array}$ & $\begin{array}{l}1.414(6) \\
1.400(5)\end{array}$ & $\begin{array}{l}1.423(6) \\
1.409(6)\end{array}$ \\
\hline & $\mathrm{C}_{4}-\mathrm{C}_{5}$ & $\begin{array}{l}1.379(13) \\
1.369(12)\end{array}$ & $\begin{array}{l}1.392(6) \\
1.378(6)\end{array}$ & $\begin{array}{l}1.412(6) \\
1.368(5)\end{array}$ & $\begin{array}{l}1.351(5) \\
1.361(5)\end{array}$ \\
\hline & $\mathrm{C}_{5}-\mathrm{C}_{6}$ & $\begin{array}{l}1.403(11) \\
1.405(11)\end{array}$ & $\begin{array}{l}1.380(6) \\
1.416(6)\end{array}$ & $\begin{array}{l}1.356(6) \\
1.427(6)\end{array}$ & $\begin{array}{l}1.413(5) \\
1.406(5)\end{array}$ \\
\hline & $\mathrm{C}_{6}-\mathrm{C}_{1}$ & $\begin{array}{l}1.432(12) \\
1.406(11)\end{array}$ & $\begin{array}{l}1.440(6) \\
1.422(6)\end{array}$ & $\begin{array}{l}1.453(5) \\
1.403(5)\end{array}$ & $\begin{array}{l}1.425(5) \\
1.431(5)\end{array}$ \\
\hline
\end{tabular}

significantly from those of the complex before oxidation, $\mathrm{Cu}$ (Salphen-OMe) (Table 3) [51]. Although there is only a slight contraction of the $\mathrm{Cu}-\mathrm{O}$ and $\mathrm{Cu}-\mathrm{N}$ bonds, the copper ion geometry is significantly distorted toward a tetrahedral geometry in our case (the dihedral angle of $22^{\circ}$ between the $\mathrm{O}_{1}-\mathrm{Cu}-\mathrm{N}_{1}$ and $\mathrm{O}_{2}-\mathrm{Cu}-\mathrm{N}_{2}$ planes). These structural features indicate that the oxidation locus of $[\mathrm{Cu}(\text { Salphen-OMe })]^{+}$is neither the two phenolates nor the central copper ion. A striking feature upon oxidation is the change in the bond lengths within the phenyl ring, and in addition the counterion $\mathrm{SbF}_{6}^{-}$is located close to the $o$-phenylenediamine moiety. The $\mathrm{C}-\mathrm{C}$ and $\mathrm{C}-\mathrm{N}$ bond lengths of the $o$-phenylenediamine moiety in $[\mathrm{Cu}(\mathbf{S a l}-$ phen-OMe) $]^{+}$were different from those before oxidation, indicating that the $\mathrm{C}-\mathrm{N}$ bonds are contracted and the phenyl ring is distorted to the quinod form (Figure 8) [15]. Therefore, the oxidized complex, [Cu(SalphenOMe) $] \mathrm{SbF}_{6}$, can be assigned to the $\mathrm{Cu}(\mathrm{II})$-diiminobenzene radical species. In this connection, the one-electron oxidized complex without any substitution on the $o$ phenylenediamine moiety, $[\mathrm{Cu}(\text { Salphen })]^{+}$, has a different electronic structure, which corresponds to the $\mathrm{Cu}(\mathrm{II})$ phenoxyl radical species [52]. The methoxy substitution in the phenyl ring leads to a different electronic structure due to its electron donating property.

\section{Summary}

X-ray crystal structures of the one-electron oxidized species of metal-phenolate complexes and metal(II) salentype complexes are discussed in this review with reference to the relationship between geometrical and electronic structures. Significant structural changes from the precursor complexes are not detected in these radical complexes, since the phenoxyl radical complexes are

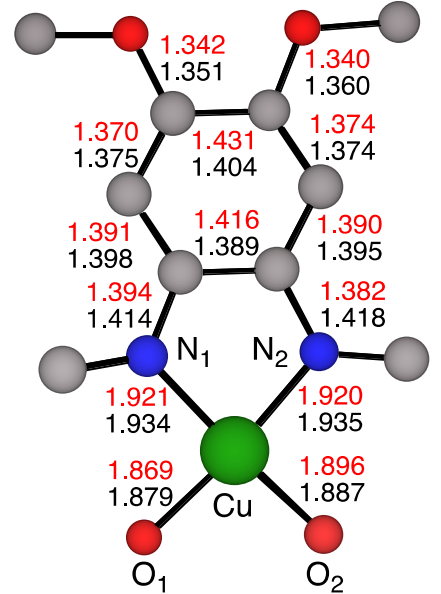

Figure 8. Bond lengths of the diiminobenzene moiety in $\mathrm{Cu}$ (Salophe-OMe) (black) and $[\mathrm{Cu}(\mathrm{Salophe}-\mathrm{OMe})] \mathrm{SbF}_{6}$ (red).

generated as the simple electron transfer reaction products. However, subtle structural changes were detected by the recent X-ray crystal structure analyses. The structural changes of phenolate ligands are rather small in comparison to the spectroscopic changes, but they are significant and important for understanding the detailed electronic structure of the oxidized metal phenolate complexes. The ligand oxidation product, the metal-phenoxyl radical complex, showed in general the quinoid configuration, especially for the $p$-methoxyphenoxyl radical due to its canonical forms. On the other hand, high-valent metal phenolate complexes, which are in the same formal oxidation state but with a different experimental valence state, exhibited the difference from the metal-phenoxyl radical complexes, whose metal phenolate oxygen bond length is contracted while the phenolate ligand $\mathrm{C}-\mathrm{O}$ and $\mathrm{C}-\mathrm{C}$ bond lengths do not show significant changes. Prop- 
erties related with such structural features have been also observed in various physicochemical studies.

The structural features of metal-phenoxyl radical complexes are sometimes not identical, due to correlation with localization and delocalization of the radical electron. Therefore, one form of the phenoxyl radical, the quinoid form, is sometimes not clear in the crystal structures, while the structures of the phenolate moieties in delocalized complexes differ from the phenolate moiety of high-valent metal phenolate and localized metal phenoxyl radical complexes. Small but significant differences due to localization and delocalization have been detected, for example, for the group 10 metal 5-membered and 6-membered chelate salen-type complexes [42-44], which indicates that X-ray crystal structure analysis can reveal detailed electronic structures of the complexes. However, detection of such structural differences is sometimes difficult, so that combination with the spectroscopic studies is important for understanding the detailed electronic structure of the target complexes. Further studies on the relationship between geometrical and electronic structures are in progress not only in our group but also in other groups. We hope to see very important and interesting results for understanding the electronic structure of the reaction intermediates based on the X-ray diffraction method.

\section{Acknowledgements}

The author is grateful to Prof. Dr. Osamu Yamauchi, Kansai University, for helpful comments and suggestions during preparation of this review.

\section{REFERENCES}

[1] R. H. Holm, P. Kennepohl and E. I. Solomon, "Structural and Functional Aspects of Metal Site in Biology," Chemical Reviews, Vol. 96, No. 7, 1996, pp. 2239-2314. doi:10.1021/cr9500390

[2] H. Sono, M. P. Roach, E. D. Coulter and J. H. Dawson, "Structure and Reaction Mechanism in the Heme Dioxygenases," Chemical Reviews, Vol. 96, No. 7, 1996, pp. 2841-2887. doi:10.1021/cr9500500

[3] B. Meunier, S. P. de Visser and S. Shaik, "Theoretical Perspective on Structure and Mechanisms of Cytochrome P450 Enzymes," Chemical Reviews, Vol. 104, No. 9, 2004, pp. 3947-3980. doi:10.1021/cr020443g

[4] M. Baik, M. Newcomb, R. A. Friesner and S. J. Lippard, "Insights into the P-to-Q Conversion in the Catalytic Cycle of Methane Monooxygenase from a Synthetic Model System," Chemical Reviews, Vol. 103, No. 6, 2003, pp. 2385-2420. doi:10.1021/cr950244f

[5] E. Y. Tshuva and S. J. Lippard, "Synthetic Models for Non-Heme Carboxylate-Bridged Diiron Metalloproteins: Strategies and Tactics," Chemical Reviews, Vol. 104, No. 2, 2004, pp. 987-1012. doi:10.1021/cr020622y

[6] M. Costas, M. P. Mehn, M. P. Jensen and L. Que Jr., "Dio- xygen Activation at Mononuclear Nonheme Iron Active Sites: Enzymes, Models, and Intermediates," Chemical Reviews, Vol. 104, No. 2, 2004, pp. 939-986. doi:10.1021/cr020628n

[7] E. I. Solomon, T. C. Brunold, M. I. Davis, J. N. Kemsley, S.-K. Lee, N. Lehnert, F. Neese, A. J. Skulan, Y.-S. Yang and J. Zhou, "Geometric and Electronic Structure/Function Correlations in Non-Heme Iron Enzymes," Chemical Reviews, Vol. 100, No. 1, 2000, pp. 235-350. doi: $10.1021 / \mathrm{cr} 9900275$

[8] W. Nam, "Special Issue on Dioxygen Activation by Metalloenzymes and Models," Accounts of Chemical Research, Vol. 40, No. 7, 2007, pp. 465-635. doi:10.1021/ar700131d

[9] A. Gunay and K. H. Theopold, "C-H Bond Activations by Metal Oxo Compounds," Chemical Reviews, Vol. 110, No. 2, 2010, pp. 1060-1081. doi:10.1021/cr900269x

[10] L. M. Mirica, X. Ottenwaelder and T. D. P. Stack, "Structure and Spectroscopy of Copper-Dioxygen Complexes," Chemical Reviews, Vol. 104, No. 2, 2004, pp. 1013-1046. doi: $10.1021 / \mathrm{cr} 020632 \mathrm{z}$

[11] E. A. Lewis and W. B. Tolman, "Reactivity of DioxygenCopper Systems," Chemical Reviews, Vol. 104, No. 2, 2004, pp. 1047-1076. doi:10.1021/cr020633r

[12] J.-U. Rohde, J. H. In, M. H. Lim, W. W. Brennessel, M. R. Bukowski, A. Stubna, E. Münck, W. Nam and L. Que Jr., "Crystallographic and Spectroscopic Characterization of a Nonheme Fe(IV)=O Complex," Science, Vol. 299, No. 5609, 2003, pp. 1037-1039. doi:10.1126/science.299.5609.1037

[13] C. K. Jörgensen, "Oxidation Numbers and Oxidation States," Springer, Heidelberg, 1969. doi:10.1007/978-3-642-87758-2

[14] P. J. Chirik and K. Wieghardt, "Radical Ligands Confer Nobility on Base-Metal Catalysts," Science, Vol. 327, No. 5967, 2010, pp. 794-795. doi:10.1126/science.1183281

[15] W. Kaim, "Manifestations of Noninnocent Ligand Behavior," Inorganic Chemistry, Vol. 50, No. 20, 2011, pp. 9752-9765. doi:10.1021/ic2003832

[16] J. Stubbe and W. A. van der Donk, "Protein Radicals in Enzyme Catalysis," Chemical Reviews, Vol. 98, No. 2, 1998, pp. 705-762. doi:10.1021/cr9400875

[17] J. W. Whittaker, "Radical Copper Oxidases," Metal Ions in Biological Systems, Vol. 30, 1994, pp. 315-360.

[18] J. W. Whittaker, "Free Radical Catalysis by Galactose Oxidase," Chemical Reviews, Vol. 103, No. 6, 2003, pp. 2347-2363. doi:10.1021/cr020425z

[19] N. Ito, S. E. V. Phillips, K. D. S. Yadav and P. F. Knowles, "Crystal Structure of a Free Radical Enzyme, Galactose Oxidase," Journal of Molecular Biology, Vol. 238, No. 5, 1994, pp. 794-814.

[20] G. R. Dyrkacz, R. D. Libby and G. A. Hamilton, “Trivalent Copper as a Probable Intermediate in the Reaction Catalyzed by Galactose Oxidase," Journal of the American Chemical Society, Vol. 98, No. 2, 1976, pp. 626-628. doi: $10.1021 / \mathrm{ja} 00418 \mathrm{a} 060$

[21] G. A. Hamilton, P. K. Adolf, J. de Jersey, G. C. DuBois, G. R. Dyrkacz and R. D. Libby, "Trivalent Copper, Su- 
peroxide, and Galactose Oxidase," Journal of the American Chemical Society, Vol. 100, No. 6, 1978, pp. 18991912. doi:10.1021/ja00474a042

[22] K. Clark, J. E. Penner-Hahn, M. M. Whittaker and J. W. Whittaker, "Oxidation-State Assignments for Galactose Oxidase Complexes from X-Ray Absorption Spectroscopy. Evidence for Copper(II) in the Active Enzyme," Journal of the American Chemical Society, Vol. 112, No. 17, 1990, pp. 6433-6435. doi:10.1021/ja00173a061

[23] M. L. McGlashen, D. D. Eads, T. G. Spiro and J. W. Whittaker, "Resonance Raman Spectroscopy of Galactose Oxidase: A New Interpretation Based on Model Compound Free Radical Spectra," Journal of Physical Chemistry, Vol. 99, No. 14, 1995, pp. 4918-4922. doi:10.1021/j100014a008

[24] P. Chaudhuri, C. N. Verani, E. Bill, E. Bothe, T. Weyhermüller and K. Wieghardt, "Electronic Structure of Bis $(o-$ iminobenzosemiquinonato)metal Complexes ( $\mathrm{Cu}, \mathrm{Ni}, \mathrm{Pd})$. The Art of Establishing Physical Oxidation States in Transition-Metal Complexes Containing Radical Ligands," Journal of the American Chemical Society, Vol. 123, No. 10, 2001, pp. 2213-2223. doi:10.1021/ja003831d

[25] D. Herebian, E. Bothe, E. Bill, T. Weyhermüller and K. Wieghardt, "Experimental Evidence for the Noninnocence of $o$-Aminothiophenolates: Coordination Chemistry of $o$-Iminothionebenzosemiquinonate(1-) $\pi$-Radicals with Ni(II), Pd(II), Pt(II)," Journal of the American Chemical Society, Vol. 123, No. 41, 2001, pp. 10012-10023. doi:10.1021/ja011155p

[26] J. Hockertz, S. Steenken, K. Wieghardt and P. Hildebrandt, "(Photo)ionization of tris(phenolato)iron(III) Complexes: Generation of Phenoxyl Radical as Ligand," Journal of the American Chemical Society, Vol. 115, No. 24, 1993, pp. 11222-11230. doi:10.1021/ja00077a022

[27] M. R. DeFilippis, C. P. Murthy, M. Faraggi and M. H. Klapper, "Pulse Radiolytic Measurement of Redox Potentials: The Tyrosine and Tryptophan Radicals," Biochemistry, Vol. 28, No. 11, 1989, pp. 4847-4853. doi:10.1021/bi00437a049

[28] J. Emsley, "The Elements," 3rd Edition, Oxford University Press, Oxford, 1998.

[29] J. A. Halfen, B. A. Jazdzewski, S. Mahapatra, L. M. Berreau, E. C. Wilkinson, L. Que Jr. and W. B. Tolman, "Synthetic Models of the Inactive Copper(II)-Tyrosinate and Active Copper(II)-Tyrosyl Radical Forms of Galactose and Glyoxal Oxidases," Journal of the American Chemical Society, Vol. 119, No. 35, 1997, pp. 8217-8227. doi:10.1021/ja9700663

[30] R. C. Pratt and T. D. P. Stack, "Intramolecular Charge Transfer and Biomimetic Reaction Kinetics in Galactose Oxidase Model Complexes," Journal of the American Chemical Society, Vol. 125, No. 29, 2003, pp. 8716-8717. doi:10.1021/ja035837j

[31] N. G. Connelly and W. E. Geiger, "Chemical Redox Agents for Organometallic Chemistry," Chemical Reviews, Vol. 96, No. 2, 1996, pp. 877-910. doi:10.1021/cr940053x

[32] E. Vinck, D. M. Murphy, I. A. Fallis, R. R. Strevens and S. Van Doorslaer, "Formation of a Cobalt(III)-Phenoxyl Radical Complex by Acetic Acid Promoted Aerobic Oxi- dation of a Co(II)salen Complex," Inorganic Chemistry, Vol. 49, No. 5, 2010, pp. 2083-2092.

doi:10.1021/ic901849e

[33] Y. Shimazaki, S. Huth, A. Odani and O. Yamauchi, "A Structural Model for the Galactose Oxidase Active Site which Shows Counteranion-Dependent Phenoxyl Radical Formation by Disproportionation," Angewandte Chemie International Edition, Vol. 39, No. 9, 2000, pp. 16661669.

doi:10.1002/(SICI)1521-3773(20000502)39:9<1666::AID -ANIE1666>3.0.CO;2-O

[34] Y. Shimazaki, S. Huth, S. Hirota and O. Yamauchi, "Studies on Galactose Oxidase Active Site Model Complexes: Effects of Ring Substituents on Cu(II)-Phenoxyl Radical Formation," Inorganica Chimica Acta, Vol. 331, No. 1, 2002, pp. 168-177. org/10.1016/S0020-1693(01)00781-2

[35] E. R. Altwicker, "The Chemistry of Stable Phenoxy Radicals" Chemistry Review, Vol. 67, No. 5, 1967, pp. 475531. doi:10.1021/cr60249a001

[36] G. N. R. Tripathi and R. H. Schuler, "Resonance Raman Studies of Substituent Effects on the Electronic Structure of Phenoxyl Radicals," The Journal of Physical Chemistry, Vol. 92, No. 18, 1988, pp. 5129-5133. doi: $10.1021 / \mathrm{j} 100329 \mathrm{a} 015$

[37] Y. Shimazaki and O. Yamauchi, "Recent Advantage in Metal-Phenoxyl Radical Chemistry," Indian Journal Chemistry Section A, Vol. 50A, No. 3-4, 2011, pp. 383-394.

[38] A. Sokolowski, E. Bothe, E. Bill, T. Weyhermüller and K. Wieghardt, "Phenoxyl Radical Complexes of Chromium (III)," Chemical Communications, No. 14, 1996, pp. 16711672. doi:10.1039/cc9960001671

[39] L. Benisvy, A. J. Blake, D. Collison, E. S. Davies, C. D. Garner, E. J. L. McInnes, J. McMaster, G. Whittaker and C. Wilson, "A Phenoxyl Radical Complex of Copper(II)," Chemical Communications, No. 18, 2001, pp. 1824-1825. doi:10.1039/b105186p

[40] L. Benisvy, A. J. Blake, D. Collison, E. S. Davies, C. D. Garner, E. J. L. McInnes, J. McMaster, G. Whittaker and C. Wilson, "A Phenol-Imidazole Pro-Ligand That Can Exist as a Phenoxyl Radical, Alone and When Complexed To copper(II) and Zinc(II)," Dalton Transactions, No. 10, 2003, pp. 1975-1985. doi:10.1039/b212209j

[41] L. Benisvy, E. Bill, A. J. Brlake, D. Collison, E. S. Davies, C. D. Garner, C. I. Guindy, E. J. L. McInnes, G. McArdle, J. McMaster, C. Wilson and J. Wolowsks, "Phenolate and Phenoxyl Radical Complexes of $\mathrm{Co}$ (II) and Co(III)," Dalton Transactions, No. 21, 2004, pp. 3647 3653. doi:10.1039/b410934a

[42] T. Storr, E. C. Wasinger, R. C. Pratt and T. D. P. Stack, "The Geometric and Electronic Structure of a One-Electron-Oxidized Nickel(II) Bis(Salicylidene)diamine Complex," Angewandte Chemie International Edition, Vol. 46, No. 27, 2007, pp. 5198-5201. doi:10.1002/anie.200701194

[43] Y. Shimazaki, T. D. P. Stack and T. Storr, "Detailed Evaluation of the Geometric and Electronic Structures of One-Electron Oxidized Group 10 (Ni, Pd, and Pt) Metal (II)-(Disalicylidene)diamine Complexes," Inorganic Chemistry, Vol. 48, No. 17, 2009, pp. 8383-8392. 
doi:10.1021/ic901003q

[44] Y. Shimazaki, N. Arai, T. J. Dunn, T. Yajima, F. Tani, C. F. Ramogida and T. Storr, "Influence of the Chelate Effect on the Electronic Structure of One-Electron Oxidized Group 10 Metal(II)-(Disalicylidene)diamine," Dalton Transactions, Vol. 40, No. 11, 2011, pp. 2469-2479. doi:10.1039/c0dt01574a

[45] Y. Shimazaki, T. Yajima, F. Tani, S. Karasawa, K. Fukui, Y. Naruta and O. Yamauchi, "Syntheses and Electronic Structures of One-Electron-Oxidized Group 10 Metal(II)(Disalicylidene)diamine Complexes (Metal = Ni, Pd, Pt), Journal of the American Chemistry Society, Vol. 129, No. 9, 2007, pp. 2559-2568. doi:10.1021/ja067022r

[46] B. Bag, N. Mondal, G. Rosair and S. Mitra, "The First Thermally-Stable Singly Oxo-Bridged Dinuclear Ni(III) Complex," Chemical Communications, No. 18, 2000, pp. 1729-1730. doi:10.1039/b004165n

[47] Y. Shimazaki, O. Yamauchi, "Group-10 Metal Complexes of Biological Molecules and Related Ligands: Structural and Functional Properties," Chemistry and Biodiversity, Vol. 9, No. 9, 2012, pp. 1635-1658. doi:10.1002/cbdv.201100446

[48] T. Storr, P. Verma, R. C. Pratt, E. C. Wasinger, Y. Shimazaki and T. D. P. Stack, "Defining the Electronic and Geometric Structure of One-Electron Oxidized CopperBis-phenoxide Complexes," Journal of the American Chemistry Society, Vol. 130, No. 46, 2008, pp. 15448-
15459. doi:10.1021/ja804339m

[49] K. Asami, K. Tsukidate, S. Iwatsuki, F. Tani, S. Karasawa, L. Chiang, T. Storr, F. Thomas and Y. Shimazaki, "New Insights into the Electronic Structure and Reactivity of One-Electron Oxidized Copper(II)-(Disalicylidene) diamine Complexes," Inorganic Chemistry, Vol. 51, No. 22, 2012, pp. 12450-12461. doi:10.1021/ic3018503

[50] M. Orio, O. Jarjayes, H. Kanso, C. Philouze, F. Neese and F. Thomas, "X-Ray Structures of Copper(II) and Nickel (II) Radical Salen Complexes: The Preference of Galactose Oxidase for Copper(II)," Angewandte Chemie International Edition, Vol. 49, No. 29, 2010, pp. 49894992. doi:10.1002/anie.201001040

[51] A. Kochem, O. Jarjayes, B. Baptiste, C. Philouze, H. Vezin, K. Tsukidate, F. Tani, M. Orio, Y. Shimazaki and F. Thomas "One-Electron Oxidized Copper(II) Salophen Complexes: Phenoxyl versus Diiminobenzene Radical Species." Chemistry - A European Journal, Vol. 18, No. 4, 2012, pp. 1068-1072. doi:10.1002/chem.201102882

[52] F. Thomas, O. Jarjayes, C. Duboc, C. Philouze, E. SaintAman and J.-L. Pierre, "Intramolecularly HydrogenBonded versus Copper(II) Coordinated Mono- and BisPhenoxyl Radicals" Dalton Transactions, No. 17, 2004, pp. 2662-2669. doi:10.1039/b406009a 